\title{
On the fossil flora of Jebel Qatrani area, Fayum, Egypt
}

\author{
Wagieh E.El-Saadawi
}

Botany Department, Faculty of Science, Ain-Shams University, Cairo, Egypt E-mail: wagelsaadawi@yahoo.com

Wagieh E.El-Saadawi. 2006. On the fossil flora of Jebel Qatrani area, Fayum, Egypt. Taeckholmia 26: 131-140.

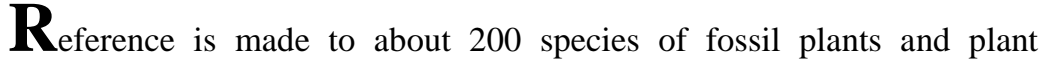
fragments previously reported from Upper Eocene to Pleistocene/ Holocene strata of Jebel Qatrani area in northern Fayum Depression. The fossils belong to algae, pteridophytes and angiosperms. Comments are made on the origin of the flora, palaeoenvironment and palaeoclimate.

Key words: Egypt, Fayum, Fossil plants, Jebel Qatrani Formation.

\section{Introduction}

The Jebel Qatrani area*, considered here $\left(29^{\circ} 25^{\prime} 00^{\prime \prime}-29^{\circ} 45^{\prime} 00^{\prime \prime}\right.$ $\mathrm{N} \& 30^{\circ} 20^{\prime} 00^{\prime \prime}-3050^{\prime} 00^{\prime \prime}$ E, Fig.1) is as rich in fossil plants as it is in fossil animals (mammals, other vertebrates, invertebrates, insects, ----etc). Fossil plants reported on include; angiosperms, pteridophytes and algae. There are reports on casts, petrifactions and other types of fossilized plant remains .Reported plant remains include: stems, leaves, fruits, seeds, roots, rhizoliths, thalloid and unicellular algae as comes below.

* A nomination file for the inscription of this area on the Natural \& Cultural World Heritage list is being prepared at present by concerned authorities in Egypt.

Received 15 October 2006, Revision accepted 12 December 2006 


\section{I-Fossil stems}

\section{Wood logs and reeds}

\section{a- Wood logs}

Petrified wood logs occur at random in various localities of Jebel Qatrani Formation. They form "forests" consisting of a few to about 200 logs. The logs range in diameter from $15 \mathrm{~cm}$ to $2 \mathrm{~m}$ and in length from a few meters to more than $44 \mathrm{~m}$. Small pieces of silicified wood are abundantly associated with the fossil logs. Upright boles of silicified trees are sporadically found at or just above the contact between the Oligocene Jebal Qatrani Formation and the Miocene Khashab Formation.

Fourteen wood species in eight angiosperm families (seven dicots and one monocot) have been reported on from the J.Q. area by: Blanckenhorn (1921),Kräusel (1939), Wing \& Tiffney (1982a), Dupéron-Laudoueneix \& Dupéron (1995), El-Saadawi \& Kamal-El-Din (2004), and El-Saadawi et al. (2004):

- Bombacaceae, Bombacoxylon oweni (Carruthers) Gottwald, Early Oligocene, Fayum.

- Combretaceae, Terminalioxylon intermedium (Kräusel) Mädel \& MüllerStoll (=Combretoxylon bussoni (Louvet) louvet), Oligocene, J.Q. (29०37' $00^{\prime \prime} \mathrm{N}, \& 30^{\circ} 40^{\prime} 00^{\prime \prime}$ E). Terminalioxylon primigenium (Schenk) Mädel \&Müller-Stoll, Oligocene, J.Q. (29 37' 00" N \& 30 40' 00" E).

- Leguminosae, Detarioxylon aegyptiacum (Unger) Louvet, Late Eocene/ Early Oligocene, Qarun Lake.; ? Leguminoxylon sp., Early Oligocene, J.Q.

- Moraceae, Ficoxylon blanckenhorni Kräusel, Early Oligocene, Fayum.

- Palmae, Palmoxylon aschersoni Schenk, Oligocene,J.Q.; Palmoxylon geometricum Sahni, Late Eocene/Early Oligocene, J.Q.; Palmoxylon Lacunosum (Unger) Fel., Oligocene, J.Q.; Palmoxylon Libycum (Stenzel) Kräusel, Oligocene, J.Q.; Palmoxylon pondicherriense Sahni, Late Eocene/Early Oligocene, J.Q.

- Sapindaceae, Sapindoxylon stromeri Kräusel, Early Oligocene, J.Q.

- Sterculiaceae, Sterculioxylon giarabubense (Chiarugi )Kräusel, Early Oligocene, Qarun Lake .

- Tamaricaceae, Tamaricoxylon africanum (Kräusel) Boureau, "Pleistocene/Holocene", Dimé (on the surface), suggested to have slipped from Early Oligocene beds of J.Q. 


\section{b-Reeds}

Well-preserved silicified culms of only one fossil reed had been reported from the area (though under different names) by: Blanckenhorn (1901), Kräusel \& Stromer (1924), Soliman (1964), and El-Saadawi et al. (1975):

- Gramineae, Phragmites australis Trin. (=P.communis L.), Pleistocene, north of Dimé and at Qasr el-Sagha (associated with, also wellpreserved, silicified roots of Tamarix ).

\section{II- Fossil leaves}

Works published by Engelhardt (1907), Kräusel (1939), Wing \& Tiffney (1982a,b) Bown \& Kraus (1988), and Tiffney (1991) show that there are more than 20 species of fossil leaves recorded from the J.Q.area. Three of the reported leaf species belong to ferns ( pteridophytes ), two to monocots and all the rest are leaves of dicot plants as listed below:

- Ferns, Polypodiaceae, Acrostichum L .Oligocene, J.Q. Formation; Stenochlaena J.Sm., Oligocene, J.Q.F. (mentioned by Tiffney (1991) as an example of epiphytes in an abstracted talk).

- Ferns, Salviniaceae, Salvinia (Mich.) Schreb., Oligocene, J.Q.F.

- Monocots, Palmae, a fan-palm leaf, Oligocene, J.Q.F.

- Monocots, Typhaceae, a Typha-like leaf, Oligocene, J.Q.F.

- Lauraceae, Litsea engelhardti Kräusel, Late Eocene, north Dimé.

- Leguminosae, Cynometra L., Oligocene, J.Q.F.

- Moraceae, Ficus leucopteroides Engelhardt, Late Eocene, north Dimé; Ficus stromeri Engelhardt, Late Eocene, north Dimé.

- Myrsinaceae, Maesa zitteli Engelhardt, Late Eocene,north Dimé.

- Nelumbonaceae, Nelumbo (Tourn.) Adans., Oligocene, J.Q.F.

- Nymphaeaceae, ? Nymphaeites sp. Late Eocene, north Dimé

- Ochnaceae, one leaf type, Oligocene, J.Q.F.

- Sapotaceae, one leaf type, Oligocene, J.Q.F.

- Sterculiaceae, Triplochiton K. Schum., Oligocene, J.Q.F. And there are seven other Kinds of unidentified dicot leaves.

\section{III- Fossil fruits and seeds}

Fossil fruits and seeds from J.Q. area were reported on, from several locaities, by: Engelhardt (1907), Renner (1907), Kräusel \& Stromer (1924) ,Kräusel (1939), Simons \&Wood (1968), Wing \& Tiffney (1982a,b), and 
Tiffney (1991). These authors reported on the following taxa (representing two monocot and six dicot families):

- Monocots, Araceae, Epipremnum Schott, Early Oligocene, J.Q.

- Monocots, Palmae, one palm fruit, Tertiary, Fayum.

- Anacardiaceae, (mentioned by Tiffney (1991) in an abstracted talk).

- Anonaceae, Anonaspermum Ball, two species recorded, Oligocene, J.Q.F.

- Burseraceae, Canarium (Rumph.) L., Oligocene, J.Q.F.

- Icacinaceae, Icacinicarya Reid \& Chandler, Oligocene, J.Q.F.

- Menispermaceae, Eohypserpa Reid \& Chandler, Oligocene, J.Q.F.

- Polygalaceae, Securidaca tertiaria Engelhardt, Late Eocene, north Dimé. Wing\&Tiffney (1982a) mentioned that there are other fruit forms that are not yet identified. No main publications, however, came after 1982 (Wing, pers. com. 2006).

\section{IV- Fossil roots}

Fossil roots (casts and petrifactions) were recorded or described from J.Q. area by: Caton-Thompson \& Gardner (1934), Bowen (1970), Bowen \& Vondra (1974), Bown (1982), and El-Saadawi et al. (1987).

Root casts or rhizoliths of small plants, medium-size plants, and large plants including trees are locally abundant in J.Q.F. (Late Eocene/Early Oligocene), and are also well developed in Holocene lake margin sediments on the north shore of Qarun Lake. The rhizoliths of J.Q.F. are known to be among the best preserved and most diverse in form of such structures yet recognized in the world. Roots and rootlets ranging in diameter from $2 \mathrm{~mm}$ to $2 \mathrm{~cm}$ are usually very abundant in J.Q.F. Many specimens of wellpreserved silicified root fragments of Tamarix (Tamaricaceae, dicots) have been found (and described in rich anatomical detail) in Pleistocene, ancient lake deposits north of Dimé (occurring in association with, also wellpreserved, silicifed culm fragments of Phragmites australis already referred to).

\section{V- Fossil algae}

Reference to the occurrence of fossil thalloid macroalgae of the genus Chara in J.Q.F. had been made by Bown (1982) and Bown et al., (1982). Charophytes are known to inhabit shallow freshwater bodies. 
Unicellular microalgae (diatoms) were studied by: Aleem (1958), ElSaadawi et al., (1978), Abou El-kheir (1987), and Muller-Wilmes (1988). These authors recorded at least 159 taxa (139 spp. \& 20 varieties) of fossil diatoms from Pleistocene ancient lake deposits to the north of Qarun lake; north of Dimé and at Bacchias (35 Km east of Dimé). These authors mentioned that most of the recorded fossil diatoms are freshwater forms and that the common forms are all freshwater dwellers. The latter forms include the following species: Cyclotella kutzingiana Thw., C. meneghiniana Kütz., C. ocellata Pant., Epithemia zebra (Ehr.) Kütz .var.porcellus (Kütz.) Grun., Melosira granulata (Ehr.) Ralfs., M.islandica O.Müller, Stephanodiscus astrea (Ehr.) Grun., and S. dubius. Besides some species in the genera: Cocconeis Ehr., Cymbella Ag., Epithemia Bréb., Gomphonema Ag., and Nitzchia Hass.

\section{Origin of the flora, palaeoenvironment and palaeoclimate}

Information regarding these topics is based on the following publications: Kräusel (1939), Bowen \& Vondra (1974), Bown et al., (1982) Wing \& Tiffney (1982a,b) ; Bown \& Kraus (1988), Tiffney (1991), Dolson et al., (2002), El-Saadawi \& Kamal-El-Din (2004), and El-Saadawi et al., (2004).

\section{Origin of the flora}

Various features indicate that the J.Q.F. flora was local and not derived from another faraway locality .Among these features are: (1) Epipremnum, which is the most common fruit, is fragile, of weak construction and would not stand up to long distance fluvial transport. (2) The abundant accumulations of the large wood logs in the coarser sandstones in the lower portion of point bar deposits. (3) The presence of stubby remains of roots and of root flares at the bases of some log boles. (4) The presence of many instances of branching of the logs. (5) Logs and small wood pieces display minor effects of abrasion. (6) The presence of at least one log specimen with intact bark. (7) The presence of large rhizoliths.

These features in addition to sedimentologic evidence and geographic affinities of the flora all argue against long distance transport and in favour of deposition and fossilization not faraway from place of growth, i.e, plant remains were transported only a short distance prior to burial. 


\section{Palaeoenvironment and palaeoclimate}

The palaeofloral assemblage of the J.Q.F. includes plants of mainly three diversified habitats: brackish and marine mangrove near-shore habitat, freshwater terrestrial habitat, and freshwater aquatic habitat. Mangrove swampy habitats are indicated by presence of Cynometra which, today, includes several tropical mangrove tree and shrub species, Acrostichum which is, today, restricted to the lowland side of mangrove forests and tropical coasts, and Palmae; some of which are mangrove associates. The mangrove habitats gave way inland to freswater streams with gallery forests on alluvial ridges bordering the streams. These forests hosted trees (Bombacaceae, Burseraceae, Moraceae, ... etc), lianes, twiners and climbers (Epipremnum, Steruliaceae, Menispermaceae, Combretaceae, ... etc) and epiphytes (Stenochlaena). Shallow freshwater swamps on river sides hosted charophytes, aquatic floating plants (Nelumbo, Salvinia), and may be associated with Tamarix in gradually drier habitats. Besides these main habitats, savannahs may have existed in the interstream areas as suggested by the presence of Triplochiton.

The diversified J.Q.F. assemblage of plants has many modern counterpart taxa growing in the tropics (Indomalysia) and many others growing in monsoon climate with alternating wet and dry periods; this has supporting evidence from wood microstructure and from palaeosols.

\section{Conclusion}

The, hitherto, discovered palaeoflora of J.Q. area includes over 40 species of monocots, dicots and pteridophytes in addition to over 160 species of algae. This rich, highly diversified, and well-preserved palaeoflora (besides a wealth of discovered fossil fauna) makes this area one of the most important fossiliferous areas yet discovered in the world. Furthermore, the conditions of preservation that prevailed in the palaeoenvironment judging by the good quality of the discovered plant remains indicate that the existence of fossil fungi and fossil bryophytes (which will be the first in Egypt) is not, at all, unexpected. It is worthy to mention that all discovered plant remains are only partly studied and it is quite evident that further studies would certainly reveal more exciting information. The conservation of the J.Q area and its declaration as a site of natural (as well as cultural) world heritage really speaks for itself. 


\section{References}

Abou El-Kheir, W.S. 1987. Change in the diatom flora of Lake Qarun with time. Ain Shams Science Bulletin 26 B: 231-257.

Aleem, A.A. 1958. A taxonomic and paleoecolgical investigation of the diatom-flora of the extinct Fayoum Lake (Upper Egypt). I. Systematic part, II. Distribution and ecology. Bull. Fac. Sc. Alex. Univ. 2: 99-244.

Blanckenhorn, M. 1901. Geologie Ägyptens. Führer durch die geologische Vergangenheit Ägyptens von der Steinkohlenperiode bis zur JetztzeitBerlin.

Blanckenhorn, M. 1921. Ägypten. Handb. Region. Geol. Bd. I, Hft. 9. Heidelberg.

Bowen, B.E. 1970. The stratigraphy of the Jebel el-Qatrani Formation in the Fayum Deperssion, Egypt, U.A.R. Ph.D. Dissertation, Iowa State University (cf. Bown et al. 1982).

Bowen, B.E. and Vondra, C.F. 1974. Paleoenvironmental interpretations of the Oligocene Jebel el-Qatrani Formation, Fayum Depression, Egypt. Annals of the Geological Survey of Egypt 4:115-138.

Bown, T. M. 1982. Ichnofossils and rhizoliths of the nearshore fluvial Jebel Qatani Formation (Oligocene), Fayum Egypt. Palaeogeography, Palaeoclimatology, Palaeoecology 40:255-309.

Bown,T.M. and Kraus, M.J. 1988. Geology and palaeoenvironment of the Oligocene Jebel Qatrani Formation and adjacent rocks, Fayum Depression, Egypt. U.S. Geol. Survey Prof. Paper 1452: 1-69.

Bown,T.M., Kraus, M.J., Wing, S,L., Feagle, J.G., Tiffney, B.H., Simons, E.L., and Vondra, C.F. 1982. The Fayum Primate Forest revisited. The Journal of Human Evolution 11:603-632.

Caton-Thompson, G. and Gardner, E.W. 1934. The Desert Fayum: London, Royal Anthropolgical Institute of Great Britain and Ireland (cf. Bown and Kraus, 1988).

Dolson, I., El-Barkooky, A., Wehr, F., Gingerich, P.D., Prochazka, N. and Shann, M. 2002. The Eocene and Oligocene Paleo-Geography of Whale Valley and the Fayoum Basins: Implications for hyrocarbon Exploration in the Nile Delta and Eco-Tourism in the Greater Fayoum Basin. Cairo- AAPG/EPEX/SEG/EAGE Field Trip- no.7:1-71.

Dupéron-Laudoueneix, M. and Dupéron, J. 1995. Inventory of Mesozoic and Cenozoic woods from Equatorial and North Equatorial Africa. Rev. Palaeob. Palynol 84: 439-480. 
El-Saadawi, W., Badawi, A. and El-Awamri, A. 1975. On silicified rhizome fragments of Phragmites communis Trin. from the Pleistocene of ElFayum, Egypt. Palaeontographica Abt. B. 154: 172-178.

El-Saadawi, W., Badawi, A., and El-Awamri, A. 1987. Silicified root fragments of Tamarix L. from the Pleistocene of El-Fayum. Ann. Rev. Univ. College for Women, Ain Shams University 12: 321-335.

El-Saadawi, W., Badawi, A., Shabaan, A., and El-Awamri, A.1978. Pleistocene diatoms from El-Fayum. Proc. Egypt. Acad. Sci. 31: 257263.

El-Saadawi, W. and Kamal-El-Din, M.M. 2004. Terminalioxylon species from Gebel Qatrai Formation at Widan-el-Faras, Fayum, Egypt. Taeckholmia 24(1): 63-78.

El-Saadawi, W., Youssef, S.G.M. and Kamal-El-Din, M.M. 2004. Fosil palm woods of Egypt. II. Seven Tertiary Palmoxylon_species new to the country. Rev. Palaeob. Palynol. 129: 199-211.

Engelhardt, H. 1907. Tertiäre Pflanzenreste aus dem Fajum. Beit. z. Pal.u. Geol. Österr.-Ung.u.d. Orients 20: 206-216.

Kräusel, R. 1939. Ergebnisse der Forschungsreisen Prof. E. Stromers in den Wüsten Ägyptens. Abh. Bayer. Akad. Wiss. München 47: 1-140.

Kräusel, R. and Stromer, E.1924. Ergebnisse der Forschungsreisen Prof.E. Stromers in den Wüsten Ägyptens. Abh. Bayer. Akad. Wiss. München 30: $1-48$.

Muller-Wilmes, B. 1988. Diatomeen aus Holozanen Sedimenten des FajumSees, Ägypten. Geologisches Inst. Univ. zu Koeln, Sonderveroeffentlichungen. 64: 114pp.

Renner, O. 1907. Teichosperma, eine Monokotylenfrucht aus dem Tertiär Ägyptens. Beitr. z. Pal.u Geol. Österr.- Ung.n.d. Orients 20: 217-220.

Simons, E.L. and Wood, A.E. 1968. Early Cenozoic mammalian faunas, Fayum Province, Egypt: Peabody Museum of Natural History (Yale) Bulletin 28: 105pp.

Soliman, S.M. 1964. Silicified reed plants from the Fayum, Egypt. Amer. Journ. Sci. 262: 998-1007.

Tiffney, B.H. 1991. Paleoenvironment of the Oligocene Jebel Qatrani Formation, Fayum Depression, Northern Egypt, based on floral remains. Geol. Survey of America, 1991 Abstracts, Vol. 23, no.5, Session 178, PS- Paleontology/Paleobotany, No. 15373.

Wing, S.L. and Tiffney, B.H. 1982a. Fossil plants (p.620 in Bown et al., 1982 op.cit). 
On the fossil flora of Jebel Qatrani area, Fayum, Egypt

Wing, S.L. and Tiffney, B.H. 1982b. A paleotropical flora from the Oligocene of Jebel Qatrani Formation of northern Egypt: a preliminary report. Bot. Soc. Am., Misc. Ser. 162: 67. 
Fig. 1. Map showing Jebel Qatrani area "A" concerned and some sites mentioned in the text where; $\mathrm{B}=$ Bacchias, $\mathrm{D}=\mathrm{Dimé}, \mathrm{J} . \mathrm{Q}=$ Jebel Qatrani, L.Q= Lake Qarun and Q.S= Qasr-el-Sagha 